\title{
Epidemiological characterization of Mycobacterium caprae strains isolated from wildlife in the Bieszczady Mountains, on the border of Southeast Poland
}

Blanka Orłowska ${ }^{1 *}$, Monika Krajewska-Wędzina², Ewa Augustynowicz-Kopeć3 ${ }^{3}$, Monika Kozińska³, Sylwia Brzezińska ${ }^{3}$, Anna Zabost ${ }^{3}$, Anna Didkowska', Mirosław Welz ${ }^{4}$, Stanisław Kaczor ${ }^{5}$, Piotr Żmuda ${ }^{6}$ and Krzysztof Anusz ${ }^{1}$

\begin{abstract}
Background: The majority of animal tuberculosis (TB) cases reported in wildlife in Poland over the past 20 years have concerned the European bison inhabiting the Bieszczady Mountains in Southeast Poland: an area running along the border of Southeast Poland. As no TB cases have been reported in domestic animals in this region since 2005, any occurrence of TB in the free-living animals inhabiting this area might pose a real threat to local livestock and result in the loss of disease-free status. The aim of the study was to describe the occurrence of tuberculosis in the wildlife of the Bieszczady Mountains and determine the microbiological and molecular characteristics of any cultured strains. Lymph node samples were collected for analysis from 274 free-living animals, including European bison, red foxes, badgers, red deer, wild boar and roe deer between 2011 and 2017. Löwenstein-Jensen and Stonebrink media were used for culture. Molecular identification of strains was performed based on hsp65 sequence analysis, the GenoType ${ }^{\oplus}$ MTBC (Hain Lifescience, Germany) test, spoligotyping and MIRU-VNTR analysis.

Results: Mycobacterium caprae was isolated from the lymph nodes of 21 out of 55 wild boar (38.2\%; Cl 95\%: 26.5\%, 51.4\%) and one roe deer. Since 2014, no new TB cases have been reported in the Bieszczady European bison population.

Conclusions: The identification of TB in wild boar in the Bieszczady is an alarming phenomenon, which requires further investigation. The Bieszczady mountains are a precious, unique area, home to many protected species. However, it is also the only area in Poland where TB cases have been reported in free-living animals. The occurrence of TB in wild boar inhabiting this area might pose a real threat to local livestock and many of the protected species (for example European bison that can share feeding places with wild boar). Given this situation, ongoing monitoring of the prevalence of TB should be conducted, and protective measures should be considered.
\end{abstract}

Keywords: Wild boar, Roe deer, European bison, Badger, Mycobacterium caprae genotyping, Spoligotyping, MIRUVNTR, TB

\footnotetext{
* Correspondence: blanka_orlowska@sggw.edu.pl

${ }^{1}$ Department of Food Hygiene and Public Health Protection, Institute of

Veterinary Medicine, Warsaw University of Life Sciences (SGGW),

Nowoursynowska 166, 02-787 Warsaw, Poland

Full list of author information is available at the end of the article
}

(c) The Author(s). 2020 Open Access This article is licensed under a Creative Commons Attribution 4.0 International License, which permits use, sharing, adaptation, distribution and reproduction in any medium or format, as long as you give appropriate credit to the original author(s) and the source, provide a link to the Creative Commons licence, and indicate if changes were made. The images or other third party material in this article are included in the article's Creative Commons licence, unless indicated otherwise in a credit line to the material. If material is not included in the article's Creative Commons licence and your intended use is not permitted by statutory regulation or exceeds the permitted use, you will need to obtain permission directly from the copyright holder. To view a copy of this licence, visit http://creativecommons.org/licenses/by/4.0/ The Creative Commons Public Domain Dedication waiver (http://creativecommons.org/publicdomain/zero/1.0/) applies to the data made available in this article, unless otherwise stated in a credit line to the data. 


\section{Background}

Animal tuberculosis (TB) is a serious disease with potentially significant consequences for livestock farmers. However, while it is usually successfully detected in livestock with the use of tuberculin tests, it is challenging to identify TB-positive animals among wildlife.

Following the European Commission Decision 2009/ 342/EC of 23 April 2009, Poland was declared officially free of bovine tuberculosis. Even so, some animal tuberculosis (TB) cases (Mycobacterium caprae and Mycobacterium bovis) have been reported in wildlife in Poland over the past 20 years, with most of them concerning the European bison inhabiting the Bieszczady Mountains in Southeast Poland, a region bordered by Slovakia and Ukraine. The identification of disease outbreaks in this region resulted in the culling of two herds of European bison (Bison bonasus caucasicus), each counting more than 20 individuals: "Brzegi Dolne" (1997-2001) [1] and "Górny San" (2010-2013) [2, 3].

Another disturbing phenomenon in the Bieszczady Mountains region was the first confirmed case of TB caused by Mycobacterium caprae (M.caprae) in a wild boar (Sus scrofa) [4]: as no TB cases have been reported in domestic animals in the Bieszczady Mountains region since 2005, any occurrence of TB in free-living animals inhabiting this area might pose a real threat to local livestock and result in the loss of its disease-free status. In addition, its presence may also represent a potential source of infection for many of the other protected species inhabiting this area, such as the grey wolf, brown bear, lynx, wildcat or European bison [5]. The Bieszczady Mountains are one of the main habitat for freeliving population of European bison (lowland-Caucasian breeding line of the European bison) in Poland. The main study area, is characterized by high forest coverage (70\%) [6] and low livestock abundance: on average 5.2 cattle per $1 \mathrm{~km}^{2}, 2$ sheep per $1 \mathrm{~km}^{2}, 0.25$ goats per $1 \mathrm{~km}^{2}$ and 0.24 pigs per $1 \mathrm{~km}^{2}$ (unpublished data of the County Veterinary Inspectorate, Ustrzyki Dolne, Sanok). Of these animals, only cattle are included in the national TB eradication program, except when visible lesions suggestive of TB are identified in the animal. Unfortunately, the Bieszczady Mountains region is difficult to reach due to its mountainous terrain, with its highest peak being Tarnica at $1346 \mathrm{~m}$ a.s.l., as well as its high forest coverage and low human population. Also, it is difficult to monitor tuberculosis in the wildlife inhabiting this area, as it hosts many protected species, and diagnostic culling requires the consent of the Minister of the Environment.

To better understand the threat posed by TB, the aim of the present study was to describe the occurrence of tuberculosis in the wildlife of the Bieszczady Mountains and to determine the microbiological and molecular characteristics of the cultured strains.

\section{Results}

A total of 274 free-living animals were sampled: 156 red foxes (Vulpes vulpes), 21 badgers (Meles meles), 13 red deer (Cervus elaphus), 55 wild boar (Sus scrofa), three roe deer (Capreolus capreolus) and 26 European bison (Bison bonasus). The microbiological analysis confirmed the presence of Mycobacterium caprae in the samples collected from 21 out of 55 wild boar (38.2\%; CI 95\%: $26.5 \%, 51.4 \%$ ) in Bieszczady County and the single roe deer found near Wetlina (Cisna Commune, Lesko County) (Tables 1 and 2; Fig. 1). All 22 isolated strains of M.caprae shared an identical spoligotype 200,003,777, 377,400 - SB2391 as assigned by www.Mbovis.org [7]. From this group of 22 strains, 20 shared a single MIRUVNTR pattern $(464,652,364,413,423)$, while the other two, isolated from two wild boar, (No.18 and 22; Table 1), had patterns that differed with regard to a single locus $(464,552,364,413,423$ and $463,652,364,413,423)$ (Table 1).

Twenty wild boar displayed typical TB lesions. Of these, nineteen (Nos 3 to 21, Table 1) demonstrated multiple yellowish tubercles measuring between 1 and $5 \mathrm{~mm}$ in their submandibular or in submandibular and mediastinal lymph nodes. One wild boar was heavily infected with lungworm (No.21, Table 1). One wild boar demonstrated typical TB lesions in submandibular, mediastinal, tracheobronchial lymph nodes and in lungs (multiple yellowish tubercles up to $1 \mathrm{~cm}$ ) (No.22, Table 1). Another wild boar and the roe deer (Nos 1 and 2, Table 1) showed no anatomo-pathological lesions suggestive of TB.

\section{Discussion}

The study conducted on samples collected from 274 free-living animals in the Bieszczady Mountains, viz. 26 European bison, 55 wild boar, 13 red deer, three roe deer, 21 badgers and 156 red foxes revealed TB infections in 21 wild boar from Bieszczady County and one roe deer from Wetlina in neighboring Lesko County. Before 2011, the only documented cases of tuberculosis in the Bieszczady were observed among some European bison, a badger and three grey wolves $[1,8,9]$. Since 2014, no new TB cases have been detected among European bison in the Bieszczady region; however, some have been reported in other areas of Poland [10]. It seems, therefore, that the action taken in 2012 to 2013, during which a herd of 24 European bison infected with M.caprae was culled, together with three individuals in an enclosure in Bukowiec, Bieszczady [9, 11-13] has prevented the disease from spreading among European bison in the Bieszczady, at least for now. 
Table 1 Data about animals from which Mycobacterium caprae strains were isolated, and mycobacteria genotyping results

\begin{tabular}{|c|c|c|c|c|c|c|}
\hline No. & Species/ study year & Sex & Age & Mycobacterium species & $\begin{array}{l}\text { Spoligotype(as assigned } \\
\text { by www.Mbovis.org) }\end{array}$ & MIRU \\
\hline 1 & Roe deer /2013 & M & 7 & M.caprae & SB2391 & 464652364413423 \\
\hline 2 & Wild boar /2013 & M & 2 & M.caprae & SB2391 & 464652364413423 \\
\hline 3 & Wild boar /2013 & $\mathrm{F}$ & 2 & M.caprae & SB2391 & 464652364413423 \\
\hline 4 & Wild boar /2013 & $\mathrm{F}$ & 2 & M.caprae & SB2391 & 464652364413423 \\
\hline 5 & Wild boar /2013 & $\mathrm{F}$ & 1 & M.caprae & SB2391 & 464652364413423 \\
\hline 6 & Wild boar /2013 & $\mathrm{F}$ & 1.5 & M.caprae & SB2391 & 464652364413423 \\
\hline 7 & Wild boar /2014 & $\mathrm{F}$ & 1 & M.caprae & SB2391 & 464652364413423 \\
\hline 8 & Wild boar /2014 & $N / D$ & N/D & M.caprae & SB2391 & 464652364413423 \\
\hline 9 & Wild boar /2014 & $N / D$ & N/D & M.caprae & SB2391 & 464652364413423 \\
\hline 10 & Wild boar /2014 & N/D & N/D & M.caprae & SB2391 & 464652364413423 \\
\hline 11 & Wild boar /2014 & $N / D$ & N/D & M.caprae & SB2391 & 464652364413423 \\
\hline 12 & Wild boar /2017 & M & 1 & M.caprae & SB2391 & 464652364413423 \\
\hline 13 & Wild boar /2017 & $\mathrm{F}$ & 3 & M.caprae & SB2391 & 464652364413423 \\
\hline 14 & Wild boar /2017 & M & 2.5 & M.caprae & SB2391 & 464652364413423 \\
\hline 15 & Wild boar /2017 & $\mathrm{F}$ & 1 & M.caprae & SB2391 & 464652364413423 \\
\hline 16 & Wild boar /2017 & $N / D$ & N/D & M.caprae & SB2391 & 464652364413423 \\
\hline 17 & Wild boar /2017 & M & 2 & M.caprae & SB2391 & 464652364413423 \\
\hline 18 & Wild boar /2017 & $N / D$ & N/D & M.caprae & SB2391 & 464552364413423 \\
\hline 19 & Wild boar /2017 & M & 2 & M.caprae & SB2391 & 464652364413423 \\
\hline 20 & Wild boar /2017 & M & 0,5 & M.caprae & SB2391 & 464652364413423 \\
\hline 21 & Wild boar /2017 & $N / D$ & 0,5 & M.caprae & SB2391 & 464652364413423 \\
\hline 22 & Wild boar /2017 & $\mathrm{F}$ & N/D & M.caprae & SB2391 & 463652364413423 \\
\hline
\end{tabular}

M Male, F Female, N/D No data

Although TB was also identified in one of the investigated roe deer, the small size of tested group, i.e. three animals, does not allow firm conclusions to be drawn about the prevalence of infection in this species. In contrast, one of our more significant findings is that TB was identified in 21 of the 55 tested wild boar. The first confirmed TB case in a wild boar in the Bieszczady region

Table 2 Animals species from the Bieszczady region (Subcarpathian Voivodeship) investigated for tuberculosis in 2011-2017 and culture results

\begin{tabular}{lll}
\hline Species & \multicolumn{2}{l}{ Number of animals } \\
\cline { 2 - 3 } & investigated & $\begin{array}{l}\text { from which } \\
\text { M.caprae was } \\
\text { isolated }\end{array}$ \\
\hline Roe deer & 3 & 1 \\
Wild boar & 55 & 21 \\
Red deer & 13 & 0 \\
Badger & 21 & 0 \\
Red fox & 156 & 0 \\
$\begin{array}{l}\text { European bison from the } \\
\text { Bieszczady investigated }\end{array}$ & 26 & 0 \\
after 2013 & & \\
\hline
\end{tabular}

was reported in 2012 (a single individual) [4]; before this time, no cases of TB had been detected $[8,14]$. The population density of wild boar was found to be 5-13 animals per $10 \mathrm{~km}^{2}$ of forest in the period 2011-2017 (Forest Management Plan of the Stuposiany and Lutowiska Forest Inspectorate, 2015; Unpublished data, Stuposiany Forest Inspectorate). In the present study, all the M.caprae strains isolated from the wild boar shared the same spoligotype, i.e. SB2391, and three very similar MIRU-VNTR patterns, which differed with regard to only one locus: 464,652,364,413,423, 464,552,364,413, 423 and 463,652,364,413,423 (Table 1). It is believed that such differences in the number of repetitions at a single locus may indicate that the strains share a very close phylogenetic relationship, and that they may belong to a common transmission chain [15-17].

M.caprae strains isolated from the "Górny San" European bison herd, culled in 2011-2013, have the same spoligotype as strains isolated from boar (SB2391) and similar MIRU-VNTR patterns: 453,552,362,412,223, 453, $652,362,412,223 ， 453,552,362,413,223 ， 423,552,342,411$, 223 and 423,552,362,412,223 [3]. To our knowledge, no other registered strains with such genetic patterns have 


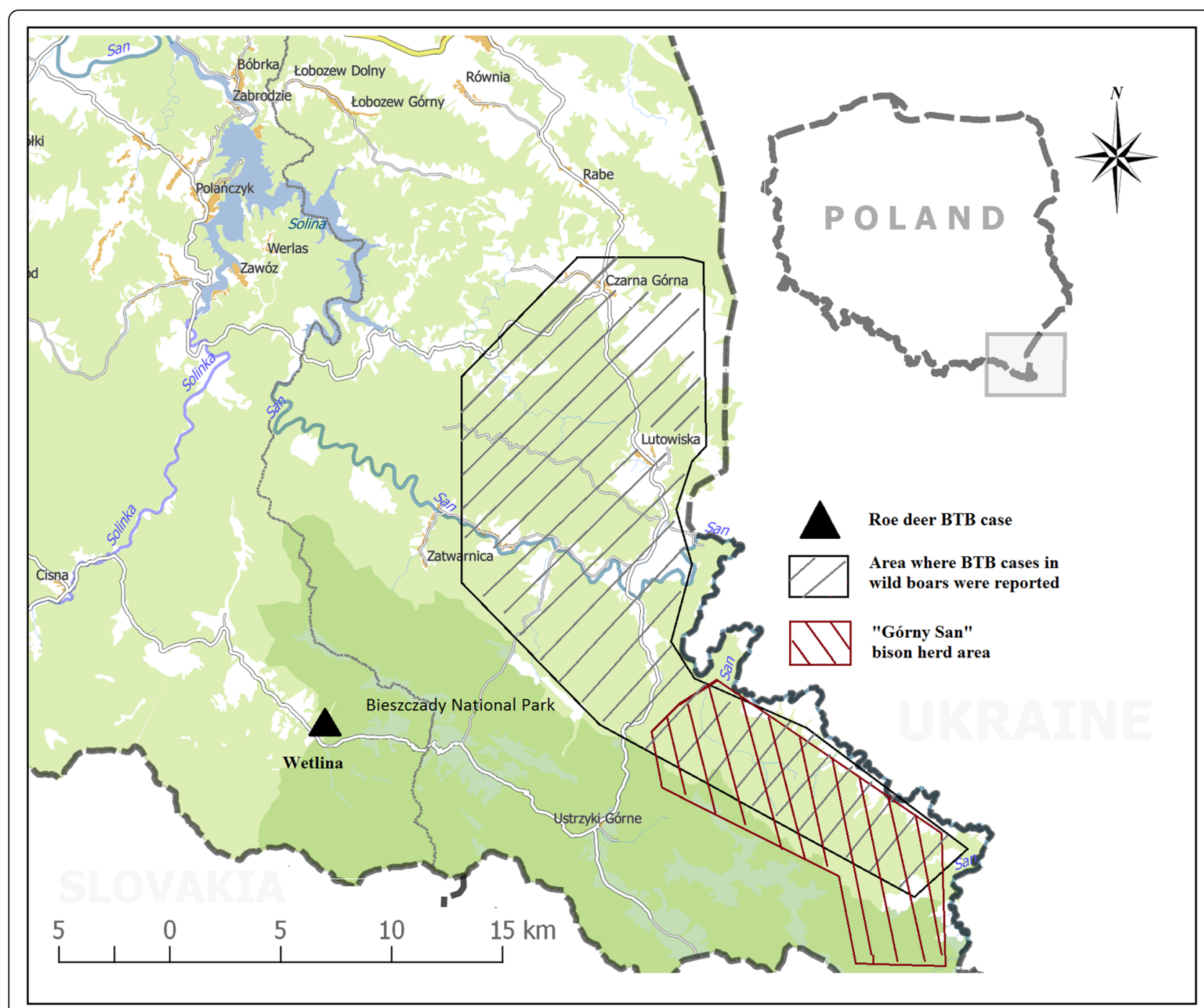

Fig. 1 The area in which TB in wild boar were reported

been entered in the available databases, including those isolated from animals from other regions. The range of "Górny San" overlapped with the area from which the infected boar were obtained (Fig. 1). It is known that wild boar can share feeding places with European bison and can feed on bison carrion. Further studies are needed to determine the epidemiological link and the possible route of transmission of the source of infection.

Although tuberculosis has been reported in boar in many European countries, the identification of $\mathrm{TB}$ in wild boar in the Bieszczady is an alarming phenomenon, and one which should be investigated further. In certain environmental conditions, wild boar are known to act as reservoirs of bacteria from the Mycobacterium tuberculosis complex (MTBC) in the environment [18-20]. M.caprae infected wild boar may be a high-risk source of infection for other animals [21].
Surprisingly, no bacteria from the MTBC were isolated from the examined foxes, badgers and red deer. As the red fox is a very effective scavenger [22, 23] a carcass of a bison or boar infected with mycobacteria from the MTBC may represent a source of infection, and the red fox may be a spillover host of tuberculosis. In fact, bacteria from the MTBC have previously been isolated from this species $[24,25]$; however, this research only studied the mandibular and mesenteric lymph nodes from red foxes. Although the mandibular and mesenteric lymph nodes are popular sources of study in $\mathrm{TB}$ research on predators, being the most common locations of lesions caused by TB infection, and mycobacteria are most often isolated from them [26, 27], subsequent studies should also include other lymph nodes, to increase their sensitivity. Together with the red fox, the Bieszczady region is also inhabited by larger predators and scavengers, such as the grey wolf, the brown bear and lynx. 
Competition between these species may significantly influence the possibility of red foxes being infected by mycobacteria from the MTBC from a carcass. The red fox, the smallest of the said predators, remains "the last to dine". The grey wolf eats most of its prey [28] and usually begins with the viscera [29]. At the same time, in deer and boar, tuberculous lesions are often found in the lymph nodes of the head, in the chest and the abdomen [30-32]. It is also possible that foxes, when they feed on carcasses, are not left with much, because the infected tissues have been eaten by the larger predators. It should be noted that M.caprae have been isolated from wolves in the Bieszczady [5].

Badgers are easily infected with mycobacteria from the MTBC and hence their populations may also act as a tuberculosis reservoir [26, 33-35]. In the Bieszczady, tuberculosis mycobacteria have so far been isolated from only one individual [8] and the number of investigated badgers from the Bieszczady County may be too low to allow for conclusions to be drawn about the occurrence of tuberculosis in this population. It should be pointed out, however, that the density of population of badgers in the Bieszczady is low, with the density of badger setts in continental Eurasia estimated as 1.7 sett $/ 10 \mathrm{~km}^{2}$ [36]. Studies on badgers in the West Carpathians (Silesian Beskids) have found the average family group size to be 2.3 individuals and the population density as 2.2 individuals $/ 10 \mathrm{~km}^{2}$. The average density in the Carpathians, of which the Bieszczady are a part, is suspected to be similar [37].

M.caprae has been isolated on a number of occasions from red deer, indicating that it may act as a maintenance host for TB [38-42]. Although the population density of red deer was found to be 18-23 animals per $10 \mathrm{~km}^{2}$ of forest in the period 2011 to 2017, (Forest Management Plan of the Stuposiany and Lutowiska Forest Inspectorate, 2015; Unpublished data, Stuposiany Forest Inspectorate), few deer in this population have been studied for the presence of TB. The Bieszczady Mountains are also inhabited by a number of predatory species, such as wolves and bears. In this area, wolves prey mainly upon red deer, constituting over $70 \%$ of their consumed biomass, followed by European roe deer and wild boar [43, 44]. It would be worth investigating whether wolves play a regulatory role for populations if wild ungulates affected by TB in this area [5].

The high forest coverage, mountainous terrain, low livestock, low abundance of badgers and the coexistence of wild ungulate and predatory species in the region may also affect the circulation of MTBC in the studied environment [45].

Our study is limited by the relatively small number of animal samples tested, and hence our findings require further confirmation. As no established program to control TB in free-living animals currently exists in Poland, the material examined in the present study was obtained through the cooperation and goodwill of various other sources, including veterinarians, employees of forest inspectorates and biologists.

\section{Conclusions}

The study conducted on samples collected from 274 free-living animals in the Bieszczady Mountains, revealed TB infections in 21 wild boar and one roe deer. The identification of TB in wild boar in the Bieszczady is an alarming phenomenon, and further studies are needed to determine the possible route of transmission and the source of infection. The occurrence of TB in wild boar inhabiting this area might pose a real threat to local livestock and many of the protected species. The Bieszczady mountains are a precious, unique area. However, it is also the only area in Poland where TB cases have been reported in free-living animals: the disease has so far been diagnosed in European bison, boar, grey wolves, as well as one roe deer and one badger $[1-5,8]$. Given this situation, ongoing monitoring of the prevalence of animal tuberculosis should be conducted, and protective measures, such as the distribution of a TB vaccine, should be considered [46-48].

\section{Methods}

\section{Sample collection}

Samples were collected from a total of 274 free-living animals between 2011 and 2017: 156 red foxes (Vulpes vulpes), 21 badgers (Meles meles), 13 red deer (Cervus elaphus), 55 wild boar (Sus scrofa), three roe deer (Capreolus capreolus) and 26 European bison (Bison bonasus). These were subjected to microbiological testing to detect $\mathrm{TB}$.

All investigated animals inhabited the Bieszczady Mountains region and their neighboring areas. The samples taken from the 156 foxes and four of the badgers were delivered by hunters to the Veterinary Hygiene Institution (VHI) in Krosno as part of the procedure for monitoring rabies and anti-rabies vaccination efficacy in red foxes. To qualify for use in mycobacterial tests, the samples had to be free from the rabies virus.

One of the roe deer, obtained from Wetlina (Cisna Commune), was a victim of a road accident (No. 1, Table 1). The European bison samples were taken from animals that had been found dead or had been culled for sanitary reasons with the consent of the Minister of Environment: the European bison samples were taken after 2013, after the elimination of the "Górny San" European bison herd.

The rest of the investigated animals had been hunted during the game season and were delivered by hunters for the study. All autopsies, age estimations and 
collection of research samples were conducted by veterinarians from the VHI in Krosno or by the County Veterinarian. Most of the investigated animals were adult individuals aged one to seven years. The samples taken from 156 foxes and four badgers by the VHI in Krosno comprised only mandibular and mesenteric lymph nodes. Among the remaining animals, all available lymph nodes were collected: the mandibular, retropharyngeal, mediastinal, tracheobronchial and mesenteric lymph nodes from all animals, together with the hepatic lymph nodes from the badgers.

All lymph nodes were subjected to thorough macroscopic examination. Lymph nodes with visible lesions were cultivated separately for the purposes of TB testing. The lymph nodes not displaying visible lesions collected from a given individual were pooled.

\section{Culture and molecular analysis Isolation of mycobacteria}

The collected samples were subjected to conventional procedures used for isolating mycobacteria. Briefly, the tissue samples were cleared of fat and cut into small fragments. The material was then ground and homogenized in $5 \%$ oxalic acid, with the whole being incubated for 15 minutes at $37{ }^{\circ} \mathrm{C}$. After this time, the sample was centrifuged for 10 minutes at $3000-4000 \mathrm{rpm}$. The supernatant was removed, and the sediment flushed twice in sterile $0.9 \%$ sodium chloride. The sediment was then inoculated onto Löwenstein-Jensen and Stonebrink media (Oxoid, Germany) and incubated at $37{ }^{\circ} \mathrm{C}$ for 12 weeks.

\section{Molecular analysis}

The initial molecular identification of the strains was based on analysis of the hsp 65 sequence [49]. The investigated mycobacterium species was identified using the PRASITE database [50]. As this method does not differentiate species within the Mycobacterium tuberculosis complex (MTBC), further identification of MTBC strains was then performed using the GenoType MTBC (Hain Lifescience, Germany) molecular test, combined with spoligotyping and mycobacterial interspersed repetitive units-variable number tandem repeats (MIRU-VNTR) analysis.

The GenoType MTBC assay was performed in accordance with the manufacturer's instructions. Spoligotyping was performed as described previously by Kamerbeek et al. (1997) [51]. To allow comparison with other databases, spoligotype patterns were entered in binary format into the SpolDB4 proprietary database of the Pasteur Institute of Guadeloupe [52]. Spoligotypes were also assigned according to international spoligotype nomenclature [7]. The MIRU-VNTR typing was performed using a public protocol [15]. The MIRU-VNTR-type was defined after combining the results for the 15 loci in the following order: MIRU 4, MIRU 10, MIRU 16, MIRU 26, MIRU 31, MIRU 40, VNTR 424, VNTR 577, VNTR 2165, VNTR 2401, VNTR 3690, VNTR 4156, VNTR 2163b, VNTR 1955 and VNTR 4052.

\section{Statistical analysis}

The 95\% confidence interval (CI 95\%) was calculated using Wilson score method.

The authors confirm that the ethical policies of the journal, as noted on the journal's author guidelines page, have been adhered with accordance to DIRECTIVE 2010/63/EU OF THE EUROPEAN PARLIAMENT AND OF THE COUNCIL of 22 September 2010 on the protection of animals used for scientific purposes. All samples were collected post-mortem. According to competent authorities, this kind of research does not require ethics approval with respect to Polish law.

\section{Abbreviations}

TB: Animal tuberculosis; hsp65: Heat-shock protein 65 gene; MIRU-

VNTR: Mycobacterial interspersed repetitive units-variable number tandem repeats; M.caprae: Mycobacterium caprae; VHI: Veterinary Hygiene Institution; rpm: Revolutions per minute; MTBC: Mycobacterium tuberculosis complex

\section{Acknowledgements}

The authors wish to thank Jan Łach and Emilian Skrzynecki from the VHI in Krosno, Poland, Przemysław Łoś from the County Veterinary Inspectorate in Ustrzyki Dolne and employees of forest inspectorate in Stuposiany. Financial resources: The statutory activity of National Tuberculosis and Lung Diseases Research Institute.

\section{Authors' contributions}

$\mathrm{BO}$ - participated in coordinating and designing the study, in material and data collection, in laboratory analysis and drafting the manuscript. MKW participated in laboratory analysis and drafting the manuscript. EAK participated in designing, coordination of the study and drafting the manuscript. MK - participated in laboratory analysis and drafting the manuscript. SB, AZ, AD - participated in laboratory analysis. MW, SK, PZ participated in material and data collection. KA - participated in designing, coordination of the study, in material and data collection and drafting the manuscript. The authors read and approved the final manuscript.

\section{Funding}

This study was supported by the statutory activity of National Tuberculosis and Lung Diseases Research Institute (NTLDRI), Task No 1.37. which covered molecular analysis of isolated strains. The statutory activity of NTLDRI had no role in study design, sample and data collection and analysis and preparation of the manuscript.

\section{Ethics approval and consent to participate}

The authors confirm that the ethical policies of the journal, as noted on the journal's author guidelines page, have been adhered with accordance to DIRE CTIVE 2010/63/EU OF THE EUROPEAN PARLIAMENT AND OF THE COUNCIL of 22 September 2010 on the protection of animals used for scientific purposes. All samples were collected post-mortem. According to competent authorities, this kind of research does not require ethics approval with respect to Polish law.

Consent for publication

Not applicable.

Availability of data and materials

The datasets analyzed during the current study are available in the SpolDB4, SITVITWEB and Mycobacterium bovis spoligotype databases [http://wWw. pasteur-guadeloupe.fr:8081/SITVIT2/, http://www.pasteur-guadeloupe.fr/tb/ spoldb4/spoldb4.pdf, https://www.mbovis.org/database.php]. 


\section{Competing interests}

The authors declare that they have no competing interests.

\section{Author details}

'Department of Food Hygiene and Public Health Protection, Institute of Veterinary Medicine, Warsaw University of Life Sciences (SGGW),

Nowoursynowska 166, 02-787 Warsaw, Poland. 'Department of Microbiology, National Veterinary Research Institute, Partyzantów 57, 24-100 Puławy, Poland. ${ }^{3}$ Department of Microbiology, National Tuberculosis and Lung Diseases Research Institute (NTLD), Płocka 26, 01-138 Warsaw, Poland. ${ }^{4}$ General Veterinary Inspectorate, Wspólna 30, 00-930 Warsaw, Poland. ${ }^{5}$ County Veterinary Inspectorate, Młynarska 45, 38-500 Sanok, Poland. ${ }^{6}$ University Centre of Veterinary Medicine UJ-UR, al. Mickiewicza 24/28, 30-059 Cracow, Poland.

Received: 25 May 2020 Accepted: 17 September 2020 Published online: 29 September 2020

\section{References}

1. Welz M, Anusz K, Salwa A, Zaleska M, Bielecki W, Osińska B, Kaczor S, Kita J. Bovine tuberculosis in European bison in the Bieszczady region. Med Weter. 2005;61:441-4

2. Krajewska M, Zabost A, Welz M, Lipiec M, Orłowska B, Anusz K, Brewczyńsk P, Augustynowicz-Kopeć E, Szulowski K, Bielecki W, Weiner M. Transmission of Mycobacterium caprae in a herd of European bison in the Bieszczady Mountains, Southern Poland. Eur J Wildl Res. 2015:61:429-33.

3. Krajewska-Wędzina M, Kozińska M, Orłowska B, Weiner M, Szulowski K, Augustynowicz-Kopeć E, Anusz K, Smith NH. Molecular characterisation of Mycobacterium caprae strains isolated in Poland. Vet Rec. 2018;74:133-8.

4. Krajewska M, Lipiec M, Zabost A, Augustynowicz-Kopeć E, Szulowski K Bovine tuberculosis in a wild boar (Sus scrofa) in Poland. J Wildl Dis. 2014;50: 1001-2.

5. Orłowska B, Augustynowicz-Kopeć E, Krajewska M, Zabost A, Welz M, Kaczor S, Anusz K. Mycobacterium caprae transmission to free-living grey wolves (Canis lupus) in the Bieszczady Mountains in Southern Poland. Eur J Wildl Res. 2017:63:21.

6. Cierpiał-Wolan M. Environmental protection in Podkarpackie voivodship in 2010-2012. Rzeszów, November 2013, ISSN 1643 - 0271.

7. Smith NH, Upton P. Naming spoligotype patterns for the RD9-deleted lineage of the Mycobacterium tuberculosis complex; www.Mbovis.org. Infect Genet Evol. 2012;12:873-6.

8. Kita J, Anusz K, Salwa A, Welz M, Orłowska B, Zalewska M. Bovine Tuberculosis in European Bison as possible zoonotic impact in Poland. In: Lorenzo-Morales J, editor Zoonosis 2012. p. 101-110.

9. Krajewska M, Welz M, Brewczyński P, Orłowska B, Anusz K. Bovine tuberculosis in the Bieszczady bison population. Życie Wet. 2014;89:148-15.

10. Krajewska M, Orłowska B, Anusz K, Welz M, Bielecki W, Wojciechowska M, Lipiec M. Szulowski K. Bovine tuberculosis in the bison herd in Smardzewice. Życie Wet. 2016;91:50-3.

11. Anusz K, Orłowska B, Krajewska-Wędzina M, Augustynowicz-Kopeć E, Krzysiak M, Bielecki W, Witkowski L, Welz M, Kita J. Ante-mortem and postmortem tuberculosis diagnostics in three European Bison from the enclosure in Bukowiec in the Bieszczady National Park in Poland. Med weter. 2017;73:642-6.

12. Brewczyński P. The current activities for protection and breeding of European bison in Bieszczady. Europ Bison Conserv Newslett. 2013;6:123-32.

13. Mazur J. Wisents in Forest District Stuposiany. Europ Bison Conserv Newslett. 2013;6:133-44.

14. Witkowski L, Orłowska B, Rzewuska M, Czopowicz M, Welz M, Anusz K, Kita J. Evidence of low prevalence of mycobacterial lymphadenitis in wild boars (Sus scrofa) in Poland. Acta Vet Scand. 2017:59:9.

15. Alonso-Rodríguez N, Martínez-Lirola M, Herránz M, Sanchez-Benitez M, Barroso P. Evaluation of the new advanced 15-loci MIRU-VNTR genotyping tool in Mycobacterium tuberculosis molecular epidemiology studies. BMC Microbiol. 2008;24:8-34.

16. van Deutekom H, Supply $\mathrm{P}$, de Haas PE, Willery E, Hoijng SP, Locht C, Coutinho RA, van Soolingen D. Molecular typing of Mycobacterium tuberculosis by mycobacterial interspersed repetitive unit-variable-number tandem repeat analysis, a more accurate method for identifying epidemiological links between patients with tuberculosis. J Clin Microbiol. 2005:43:4473-9.
17. Savine E, Warren RM, van der Spuy GD, Beyers N, van Helden PD, Locht C, Supply P. Stability of variable-number tandem repeats of mycobacterial interspersed repetitive units from 12 loci in serial isolates of Mycobacterium tuberculosis. J Clin Microbiol. 2002:40:4561-6.

18. Gortázar C, Torres MJ, Vicente J, Acevedo P, Reglero M, de la Fuente J, Negro JJ, Aznar-Martín J. Bovine tuberculosis in Doñana biosphere reserve: the role of wild ungulates as disease reservoirs in the last Iberian lynx strongholds. PloS One. 2008. doi:https://doi.org/10.1371/journal.pone. 0002776 .

19. Gortázar C, Delahay RJ, McDonald RA, Boadella M, Wilson GJ, Gavier-Widen $D$, Acevedo P. The status of tuberculosis in European wild mammals. Mammal Rev. 2012;42:193-206.

20. Vieira-Pinto M, Alberto J, Aranha J, Serejo J, Canto A, Cuhna MV, Botelho A. Combined evaluation of bovine tuberculosis in wild boar (Sus scrofa) and red deer (Cervus elaphus) in central-east Portugal. Eur J Wildl Res. 2011;57: 1189-202.

21. García-Jiménez WL, Benítez-Medina JM, Fernández-Llario P, Abecia JA, García-Sánchez A, Martínez R, Risco D, Ortiz-Peláez A, Salguero FJ, Smith NH, Gómez L. Hermoso de Mendoza J. Comparative Pathology of the Natural infections by Mycobacterium bovis and by Mycobacterium caprae in wild boar (Sus scrofa). Transboundary Emerg Dis. 2013;60:102-9.

22. Jędrzejewski W, Jędrzejewska B. Foraging and diet of the red fox Vulpes vulpes in relation to variable food resources in Bialowieza National Park, Poland. Ecography. 1992;15:212-20.

23. Selva N, Jędrzejewska B, Jędrzejewski W, Wajrak A. Factors affecting carcass use by a guild scavengers in European temperate woodland. Can J Zool. 2005:83:1590-601.

24. Michelet L, De Cruz K, Hénault S, Tambosco J, Richomme C, Réveillaud É, Gares H, Moyen JL, Boschiroli ML. Mycobacterium bovis infection of red fox, France. Emerg Infect Dis. 2018;24:1150-3.

25. Steinparzer R, Stanclova G, Bagó Z, Revilla-Fernández S, Leth C, Hofer E, Poh B, Schmoll F. Generalized Tuberculosis due to Mycobacterium caprae in a Red Fox (Vulpes vulpes) in Austria. J Wildl Dis. 2020. doi:https://doi.org/10. 7589/2019-10-249.

26. Delahay RJ, Smith GC, Barlow AM, Walker N, Harris A, Clifton-Hadley RS, Cheeseman CL. Bovine tuberculosis infection in wild mammals in the South-West region of England: a survey of prevalence and a semiquantitative assessment of the relative risks to cattle. Vet J. 2007;173:287301.

27. VerCauteren KC, Atwood TC, DeLiberto TJ, Smith HJ, Stevenson JS, Thomsen BV, Gidlewski T, Payeur J. Sentinel-based Surveillance of Coyotes to Detect Bovine Tuberculosis, Michigan. Emer Infect Dis. 2008;14:1862-9.

28. Gula R. Influence of snow cover on wolf Canis lupus predation patterns in Bieszczady Mountains, Poland. Wildl Biol. 2004;10:17-23.

29. Peterson RO, Ciucci P. The wolf as a Carnivore. In: Wolves: Mech D, Boitani $\mathrm{L}$, editors. Wolves Behavior, Ecology and Conservation, University of Chicago Press; 2003.

30. Johnson LK, Liebana E, Nunez A, Spencer Y, Clifton-Hadley R, Jahans K, Ward A, Barlow A, Delahay RJ. Histological observations of bovine tuberculosis in lung and lymph node tissues from British deer. Vet J. 2008;175:409-12.

31. Martin-Hernando PM, Hofle U, Vicente J, Ruiz-Fons F, Vidal D, Barral M, Garrido JM, de la Fuente J, Gortázar C. Lesions associated with Mycobacterium tuberculosis complex infection in the European wild boar. Tuberculosis. 2007;87:360-7.

32. Martin-Hernando MP, Torres MJ, Aznar J, Negro JJ, Gandia A, Gortázar C. Distribution of Lesions in Red and Fallow Deer Naturally Infected with Mycobacterium bovis. J Comp Pathol. 2010;142:43-50.

33. Balseiro A, González-Quirós P, Rodríguez Ó, Copano MF, Merediz I, de Juan L, Chambers MA, Delahay RJ, Marreros N, Royo LJ, Bezos J, Prieto JM, Gortázar C. Spatial relationships between Eurasian badgers (Meles meles) and cattle infected with Mycobacterium bovis in Northern Spain. Vet J. 2013;197:739-45.

34. Balseiro A, Rodríguez O, González-Quirós P, Merediz I, Sevilla IA, Davé D, Dalley DJ, Lesellier S, Chambers MA, Bezos J, Muńoz M, Delahay RJ, Gortázar C, Prieto JM. Infection of Eurasian badgers (Meles meles) with Mycobacterium bovis and Mycobacterium avium complex in Spain. Vet J. 2011;190:21-5.

35. Corner LAL, O'Meara D, Costello E, Lesellier S, Gormley E. The distribution Mycobacterium bovis infection in naturally infected badgers. Vet J. 2012;194: 166-72.

36. Kowalczyk R, Bunevich AN, Jędrzejewska B. Badger density and distribution of setts in Białowieża Primeval Forest (Poland and Belarus) compared to other Eurasian population. Acta Theriol. 2000;45:395-408. 
37. Mysłajek RW, Nowak S, Rożen A, Jędrzejewska B. Factors shaping population density, demography and spatial organization of the Eurasian badger Meles meles in mountains - the Western Carpathians (Southern Poland) as a case study. Animal biol. 2012;62:479-92.

38. Chiari M, Zanoni M, Alborali LG, Zanardi G, Avisani D, Tagliabue S, Gaffuri A, Pacciarini ML, Boniotti MB. Isolation of Mycobacterium caprae (Lechtal genotype) from red deer (Cervus elaphus) in Italy. J Wildl Dis. 2014;50:330-3.

39. Dorn-In $\mathrm{S}$, Körner T, Büttner $\mathrm{M}$, Hafner-Marx A, Müller M, Heurich M, Varadharajan A, Blum H, Gareis M, Schwaiger K. Shedding of Mycobacterium caprae by wild red deer (Cervus elaphus) in the Bavarian alpine regions, Germany. Transboundary Emerg Dis. 2020;67:308-17.

40. Schoepf K, Prodinger WM, Glawischnig W, Hofer E, Revilla-Fernandez S, Hofrichter J, Fritz J, Köfer J, Schmoll F. A Two-Years' Survey on the Prevalence of Tuberculosis Caused by Mycobacterium caprae in Red Deer (Cervus elaphus) in the Tyrol, Austria. ISRN Vet Sci. 2012. doi:https://doi.org/ 10.5402/2012/245138.

41. Nigsch A, Glawischnig W, Bagó Z, Greber N. Mycobacterium caprae infection of red deer in Western Austria-Optimized Use of Pathology Data to Infer Infection Dynamics. Front Vet Sci. 2018;5:350.

42. Fink M, Schleicher C, Gonano M, et al. Red deer as maintenance host for bovine tuberculosis, Alpine region. Emerg Infect Dis. 2015;21:464-7.

43. Śmietana W, Wajda J. Wolf number changes in Bieszczady National Park, Poland. Acta Theriol. 1997;42:241-52.

44. Jędrzejewski W, Niedziałkowska M, Hayward MW, Goszczyński J, Jędrzejewska B, Borowik T, Bartoń KA, Nowak S, Harmuszkiewicz J, Juszczyk A, Kałamarz T, Kloch A, Koniuch J, Kotiuk K, Mysłajek RW, Nędzyńska M, Olczyk A, Telon M, Wojtulewicz M. Prey choice and diet of wolves related to ungulate communities and wolf subpopulations in Poland. J Mammal. 2012; 93:1480-92.

45. Santos N, Richomme C, Nunes T, Vicente J, Alves PC, de la Fuente J, CorreiaNeves M, Boschiroli M-L, Delahay R, Gortázar C. Quantification of the Animal Tuberculosis Multi-Host Community Offers Insights for Control. Pathogens. 2020;9:421.

46. Arrieta-Villegas C, Perálvarez T, Vidal E, Puighibet Z, Moll X, Canturri A, Sevilla IA, Espada Y, Juste RA, Domingo M. Pérez de Val B. Efficacy of parenteral vaccination against tuberculosis with heat-inactivated Mycobacterium bovis in experimentally challenged goats. PLoS One. 2018. doi:https://doi.org/10. 1371/journal.pone.0196948,

47. Beltrán-Beck B, Romero B, Sevilla IA, Barasona JA, Garrido JM, GonzálezBarrio D, Díez-Delgado I, Minguijón E, Casal C, Vicente J, Gortázar C, Aranaz A. Assessment of an oral Mycobacterium bovis BCG vaccine and an inactivated $M$. bovis preparation for wild boar in terms of adverse reactions, vaccine strain survival, and uptake by nontarget species. Clin Vaccine Immunol. 2014:21:12-20.

48. Gortázar C, Beltrán-Beck B, Garrido JM, Aranaz A, Sevilla IA, Boadella M, Lyashchenko KP, Galindo RC, Montoro V, Domínguez L, Juste R, de la Fuente J. Oral re-vaccination of Eurasian wild boar with Mycobacterium bovis BCG yields a strong protective response against challenge with a field strain. BMC Vet Res. 2014. doi:https://doi.org/10.1186/1746-6148-10-96.

49. Telenti A, Marchesi F, Balz M, Bally F, Bottger EC, Bodmer T. Rapid identification of mycobacteria to the species level by polymerase chain reaction and restriction enzyme analysis. J Clin Microbiol. 1993;31:175-8.

50. The PRASITE. database. http://app.chuv.ch/prasite/index.html.

51. Kamerbeek J, Schouls L, Kolk A, van Agterveld M, van Soolingen D, Kuijper S, Bunschoten A, Molhuizen H, Shaw R, Goyal M, van Embden J. Simultaneous detection and strain differentiation of Mycobacterium tuberculosis for diagnosis and epidemiology. J Clin Microbiol. 1997;35:907-14.

52. Brudey K, Driscoll JR, Rigouts L, Prodinger WM, Gori A, Al-Hajoj SA, Allix C, Aristimuño $\mathrm{L}$, et al. Mycobacterium tuberculosis complex genetic diversity: mining the fourth international spoligotyping database (SpolDB4) for classification, population genetics and epidemiology. BMC Microbiol. 2006;6: 6-23.

\section{Publisher's Note}

Springer Nature remains neutral with regard to jurisdictional claims in published maps and institutional affiliations.

\section{Ready to submit your research? Choose BMC and benefit from:}

- fast, convenient online submission

- thorough peer review by experienced researchers in your field

- rapid publication on acceptance

- support for research data, including large and complex data types

- gold Open Access which fosters wider collaboration and increased citations

- maximum visibility for your research: over $100 \mathrm{M}$ website views per year

At BMC, research is always in progress.

Learn more biomedcentral.com/submissions 